\title{
Molecular Identification of Adenocephalus pacificus (Cestoda) from Three Human Cases in Lima Province, Peru
}

\author{
Aarón Mondragón-Martínez ${ }^{1,2,3, *}$ 『D, Rosa Martínez-Rojas ${ }^{1,2}$, Enrique Garcia-Candela1, \\ Abraham Delgado-Escalante ${ }^{1,3}$, Manuel Tantaleán-Vidaurre', Lidia Cruz-Neyra² \\ ${ }^{1}$ Parasitology Laboratory of Wildlife and Zoonoses, Faculty of Biological Sciences, Universidad Nacional Mayor de San Marcos, Peru; '2Laboratory of \\ Biology and Molecular Genetics, Faculty of Biological Sciences, Universidad Ricardo Palma, Peru; ${ }^{3}$ Research and Development Department, \\ Natural Environment, Lima, Peru
}

\begin{abstract}
The Pacific tapeworm Adenocephalus pacifcus (syn. Diphyllobothrium pacificum) is a causative agent of diphyllobothriosis occurred in Pacific coast of South America, mainly in Peru. Source of infections are traditional meal from raw or undercooked marine fish such as "cebiche". We confirmed 3 new cases, one including scolex and the other two headless. A strobila $46 \mathrm{~cm}$ long without scolex was discharged from an 8-year-old boy before treatment. Specimens were confirmed morphologically by presence of tegumental protuberances on proglottids and small sized eggs. Partial sequence of cytochrome $c$ oxidase subunit 1 gene was congruent with $A$. pacificus sequences.
\end{abstract}

Key words: Adenocephalus pacificus, diphyllobothriosis, case report, zoonosis, Peru.

\section{INTRODUCTION}

On the South Pacific coast, diphyllobothriosis is caused by Adenocephalus pacificus (syn. Diphyllobothrium pacificum) being the first human case identified for Peru in 1967 [1]; and about 1,000 cases have been reported since 1950 by this etiological agent. Human infection is probably due to the frequent habit of eating raw or undercooked fish such as "cebiche" and "tiradito", typicals Peruvian dishes whose main ingredient is fish marinated in lemon juice with chili peppers prepared from different species of fish, where the plerocercoids larvae is located $[2,3]$.

The adult cestode has as permanent hosts otarids, piscivorous mammals as well as accidentally in man and dog $[4,5]$. A potential first intermediate host would be the copepods where the procercoids would be present and the second intermediate host are different marine fish species like Sarda chiliensis chiliensis, Sciaena deliciosa, Trachurus picturatus murphyi, Scomber japonicus, or Paralabrax humeralis [2,6-8]. This study is describing 3 new cases of diphyllobothriosis in Peru based on morphological as well as molecular data confirmed by mitochondrial

\footnotetext{
- Received 17 April 2020, revised 27 June 2020, accepted 27 June 2020.

*Corresponding author (amondragon@naturalenvironment.pe)

(C) 2020, Korean Society for Parasitology and Tropical Medicine

This is an Open Access article distributed under the terms of the Creative Commons

Attribution Non-Commercial License (https://creativecommons.org/licenses/by-nc/4.0) which permits unrestricted non-commercial use, distribution, and reproduction in any

medium, provided the original work is properly cited.
}

cytochrome $c$ oxidase subunit 1.

\section{CASE RECORD}

The case 1 is an 8-year-old boy, who expelled the live tapeworm from the feces without previous treatment, the mother transferred immediately it to the government health center in the San Juan of Lurigancho district, Lima province, in 2016. She mentioned that his son had not symptom and he constantly consumed "cebiche", for the reason that she works in a restaurant based in dishes of fish products. An alive incomplete mild yellowish $46 \mathrm{~cm}$ long by $7 \mathrm{~mm}$ wide headless piece of strobila was obtained. The worm was washed in saline solution and fixed in hot water (Fig. 1A). Subsequently, the patient received praziquantel $(10 \mathrm{mg} / \mathrm{kg})$ treatment and was monitored for 1 month with no evidence of infection.

The case 2 was a 37-year-old man in 2005, he regularly consumed "cebiche". The patient without symptoms expelled after praziquantel $(20 \mathrm{mg} / \mathrm{kg})$ treatment some mild yellowish fragments of headless strobila measuring $12 \mathrm{~cm}$ long by $10 \mathrm{~mm}$ wide in his feces.

In 2002, the case 3 was observed in a 25-year-old asymptomatic woman, who liked eating insufficiently cooked marine fish. She expelled in her house some proglottids. The strobila measured of $8 \mathrm{~cm}$ long by $5.4 \mathrm{~mm}$ wide tapeworm with a spatula-shaped scolex measuring $3.38 \mathrm{~mm}$ long by $2.97 \mathrm{~mm}$ 

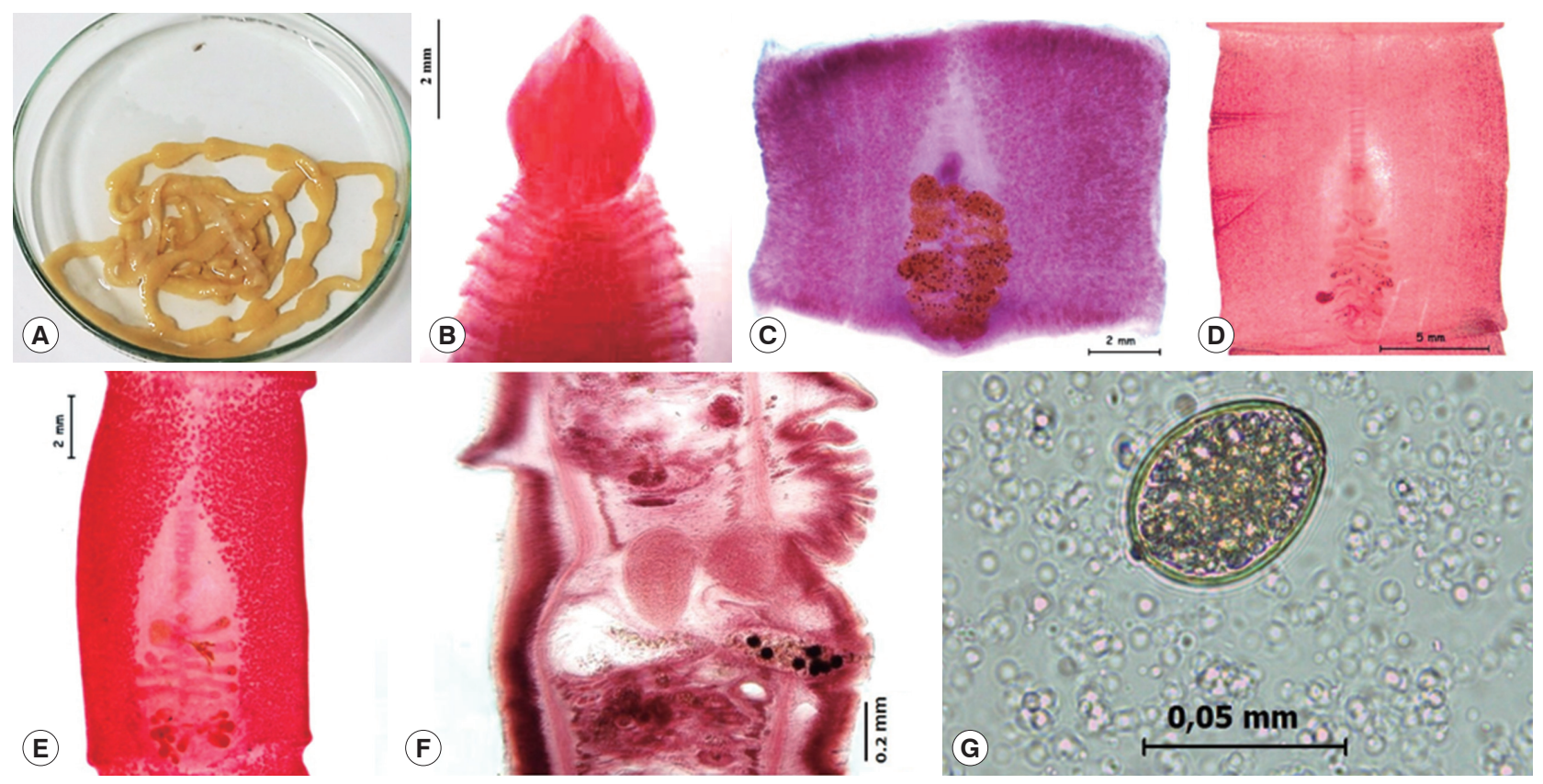

Fig. 1. Morphological features of Adenocephalus pacificus. (A) A strobila expelled alive from a child in case 1. (B) Scolex in spatulate shape stained with Semichon's acetocarmine in case 3. (C, D, E) Gravid proglottids stained with Semichon's acetic carmine in cases 1 , 2 and 3, respectively. (F) Sagittal section of a gravid proglottid. (G) An egg in stool sample.

wide (Fig. 1B). It is unknown if the patient were treated.

The samples were transferred and analyzed in the Wildlife and Zoonoses Parasitology Laboratory of the National University of San Marcos.

In this study, the 3 isolated adult cestodes were identified as A. pacificus based on presence of transverse papilla-like tegumental protuberances on ventral surface of proglottids that were observed on proglottids of all 3 cases (Fig. 1C-E).

Tapeworms were washed in saline solution, fixed in hot water and stored in $70 \%$ alcohol, kept refrigerated at $4^{\circ} \mathrm{C}$ for further study. The gravid and mature proglottids were stained with Semichon's acetic carmine and mounted in Canada balsam according to the laboratory protocol. Sagittal sections of the strobila were stained with Semichon's acetic carmine and mounted in Canada balsam, using standard histological methodology [9] (Fig. 1F). The scolex, proglottids and eggs were examined with a Leica DM750 compound microscope with phase contrast. The pictures were taken in a Leica EZ 4HD stereomicroscope.

The specific identification of the tapeworm was made by molecular analysis using PCR. Proglottids were washed 3 times with phosphate buffered saline (PBS), then the genomic DNA was extracted with the ADN DNeasy tissue Kit (Qiagen, Chatsworth, California, USA), following the manufacturer's protocol. Purity and concentration of the DNA was checked by Nanodrop 2000C spectrophotometer (Thermo Scientific, Waltham, Massachusetts, USA). The primers used were constructed as follows: DipPaCO1r (reverse, 5'-ATGATAAGGGAYAGGRGCYCA-3') common for all diphyllobothriids and DipPaCO1f (forward, 5'-ACATGTGTGTAGTAACCTTGGC-3') specific to A. pacificus, both designed by [10]. The locus was amplified by PCR in a Veriti ${ }^{\mathrm{TM}}$ 96-well thermocycler (Applied Biosystems, Foster City, California, USA) with a final volume of $50 \mu \mathrm{L}$, including $5 \mu \mathrm{L}$ of genomic DNA. The reaction mixture contained $2.5 \mathrm{U} / \mu \mathrm{l}$ Taq polymerase (HotStarTaq DNA Polymerase Qiagen Kit, Hilden, Germany), and $0.5 \mu \mathrm{M}$ of each primer (Macrogen, Korea). The amplification condition was optimized as follows: 1 cycle at $95^{\circ} \mathrm{C}$ for $5 \mathrm{~min} ; 40$ cycles of $94^{\circ} \mathrm{C}$ for $30 \mathrm{sec}, 50^{\circ} \mathrm{C}$ for $90 \mathrm{sec}$, and $72^{\circ} \mathrm{C}$ for $2 \mathrm{~min} 30 \mathrm{sec}$; and a final cycle of $72^{\circ} \mathrm{C}$ for $10 \mathrm{~min}$; storage at $4^{\circ} \mathrm{C}$. The amplified fragments were visualised on $1 \%$ agarose gel. The nucleotide sequences obtained by PCR were subjected to known sequences by BLAST search (http:// blast.ncbi.nlm.nih.gov/Blast. cgi). The lengths of the partial cox 1 sequences for cases 1,2 and 3 were 657 bp (GenBank no MN127948), 659 bp (GenBank no MN127949) and 643 bp (GenBank no MN127950), respectively. Phylogenetic relationships were evaluated with maximum likelihood (ML) in the MEGA version X program 


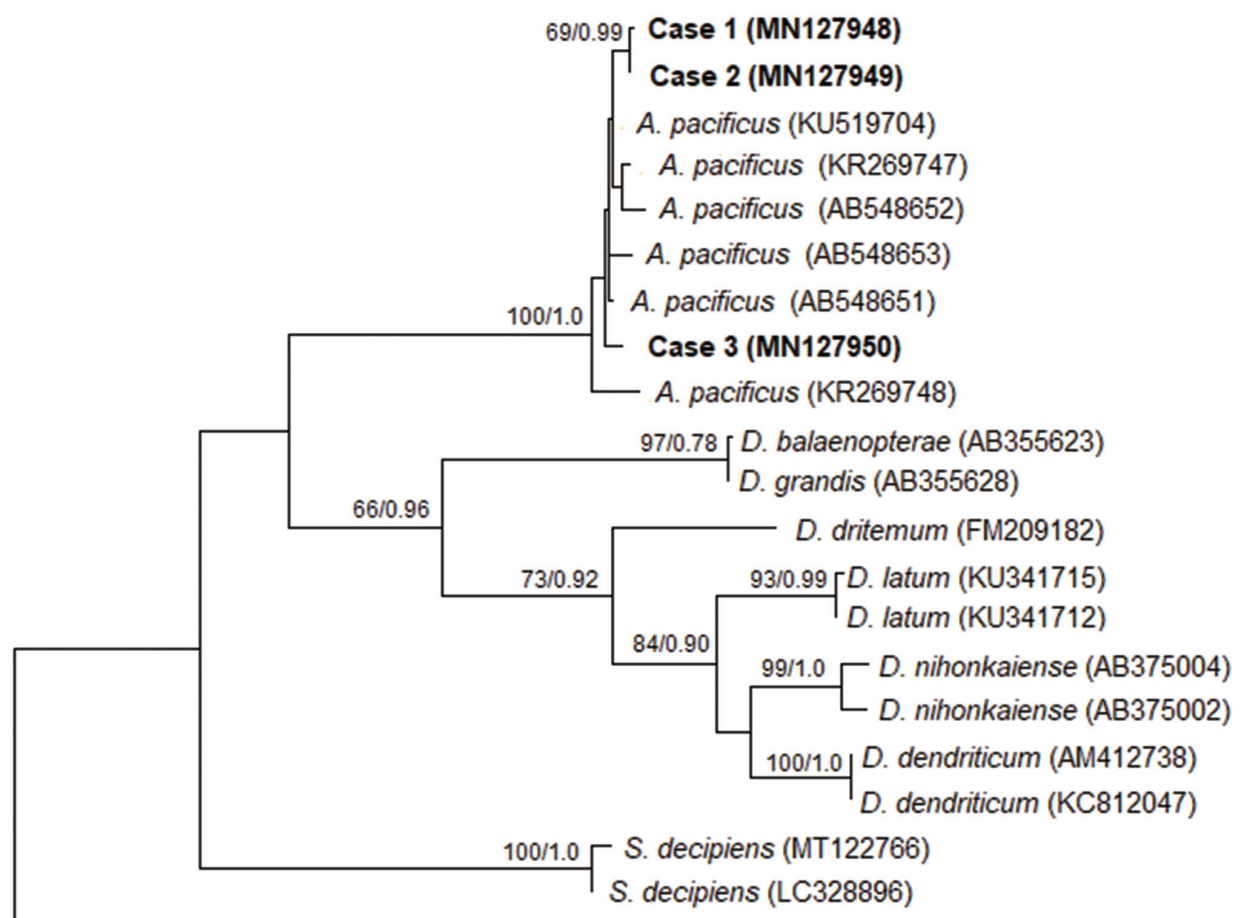

T. solium (AF360866)

0.050

Fig. 2. A phylogenetic tree of Adenocephalus pacificus partial cox1 sequences. The relationship was drawn using maximum likelihood $(\mathrm{ML})$ and Bayesian inference (BI) methods. Taenia solium was used as an outgroup. Nodal support is shown as bootstrap value (first) and posterior probability value (second) on the basis of 20 million generations for Bl and 1000 replicates for ML, respectively. GenBank accession numbers are shown in parentheses. Scale bar indicate nucleotide substitutions per site.

[11] using the Kimura's 2-parameter substitution model and the nodal support values were calculated by running 1,000 bootstrap replicates [12]. Bayesian inference criteria were analyzed in the Bayesian Evolutionary Analysis program by Sampling Trees (BEAST) version 1.7 [13]. The BIC model selected was GTR+G running a chain of 20 million generations and sampling tree topologies every 10,000 generations. The burning fraction was set at $10 \%$.

Molecular and phylogenetic diagnostics confirmed that all studied cases belonged to the species Adenocephalus pacificus (Fig. 2).

\section{DISCUSSION}

Adenocephalus pacificus, a zoonotic parasite that cause diphyllobothriosis, is directly related to the habit of consuming raw or undercooked marine fish in the form of "cebiche", "tiradito" or "chinguirito" by the habitants of the Pacific coast [14]. In this study we reported 3 new cases of infection by the same habit of consume raw fish. Health workers generally identify diphyllobothriid species based on morphological characteristics and the geographic area where their patients live. However, molecular analysis is an indispensable for accurately identifying the correct species, further, allow the acquisition of reliable epidemiological.

On the coast of Peru, the first confirmed case of human infection with A. pacificus was identified in 1967 and until now around of 1,000 cases have been reported [1,2]; therefore, only 17 human cases of A. pacificus were identified by molecular analysis between 1994 to 2008 [10]. Since 2015, no more cases have been recorded. Neighboring countries such as Chile and Ecuador have reported few cases of infection by A. pacificus compared to Peru [2].

Recently, unusual cases of human tapeworm infection have been reported in Europe, being identified by molecular analysis as A. pacificus, the presence is due to the commercial impor- 
tation of marine fish from South America, this is critical in the spread of the parasite and more attention should be paid to this emerging fish-borne zoonosis $[15,16]$. Currently, plerocercoids have been reported in other marine fish species such as Engraulis ringens, Mugil cephalus and Isacia conceptionis, potential intermediate hosts in the Pacific Ocean [17], for this, it's necessary identify potential be sources of human infection.

The eggs obtained from studied cases measured $52-55 \times 38-$ $41 \mu \mathrm{m}$ (case 1), 53-55×39-42 $\mu \mathrm{m}$ (case 2 ) and 52-54×38$40 \mu \mathrm{m}$ (case 3) (Fig. 1G), this ranges are similar to egg size of A. pacificus, $43-51 \times 35-42 \mu \mathrm{m}$ (Human, Peru), 46-54×36-42 $\mu \mathrm{m}$ (Arctocephalus pusillus, Australia) and from other registered definitive hosts [18].

Adenocephalus pacificus should be considered important in epidemiology and public health contexts, as they point to a reemerging of human diphyllobothriosis in South America, especially in Peru where the majority clinical cases are reported (>99\%) the predominant habit of eating raw or undercooked fish [2].

In conclusion, studies should be carried out on marine fish commercialized locally and exported from our country, to prevent and control this zoonotic disease. Furthermore, it is necessary to perform molecular diagnosis as a mandatory practice in health centers for the reliable identification of clinical samples and to obtain important epidemiological records.

\section{ACKNOWLEDGMENTS}

To the general directorate of research and technological transfer of the National University of San Marcos for the support provided for the development of this research. This work was supported by the funded projects program (PCONFIGIgrant number B17100721-2017).

\section{CONFLICT OF INTEREST}

All authors declare no conflict of interest.

\section{REFERENCES}

1. Baer JG, Miranda H, Fernandez W, Medina J. Human diphyllobothriasis in Peru. Z Parasitenkd 1967; 28: 277-289.

2. Kuchta R, Serrano-Martínez ME, Scholz T. Pacific broad tapeworm Adenocephalus pacificus as a causative agent of globally reemerging diphyllobothriosis. Emerg Infect Dis 2015; 21: 1697-1703.

3. Moore CV, Thompson RC, Jabbar A, Williams J, Rasiah K, Pallant L, Koehler AP, Graham C, Weldhagen GF. Rare human infection with
Pacific broad tapeworm Adenocephalus pacificus, Australia. Emerg Infect Dis 2016; 22: 1510-1512.

4. Cabrera R, Tantaleán M, Rojas R. Diphyllobothrium pacificum (Nybelin, 1931) Margolis, 1956 en Canis familiaris de la ciudad de chincha, Peru. Bol Chil Parasitol 2001; 56: 26-28 (in Spanish).

5. Hernández-Orts JS, Scholz T, Brabec J, Kuzmina T, Kuchta R. High morphological plasticity and global geographical distribution of the Pacific human broad tapeworm Adenocephalus pacificus (syn. Diphyllobothrium pacificum): molecular and morpholog ical survey. Acta Trop 2015; 149: 168-178.

6. Tantaleán VM. Hallazgo de larvas plerocercoides de Diphyllobothriidae Lihe, 1910 (Cestoda) en peces del mar peruano. Bol Chile Parasit 1975; 30: 18-20 (in Spanish).

7. Tantaleán M, Huiza A. La Diphyllobothriasis y su epidemiología en el Perú. Los hospederos paraténicos de Diphyllobothrium pacificum. Bol Med Trop UNMSM (Lima) 1984; 3: 10-11 (in Spanish).

8. Serrano-Martínez E, Quispe M, Hinostroza E, Plasencia L. Detección de parásitos en peces marinos destinados al consumo humano en Lima Metropolitana. Rev Inv Vet Perú 2017; 28: 160-168 (in Spanish).

9. Scholz T, Hanzelová V. Tapeworms of the Genus Proteocephalus Weinland, 1858 (Cestoda: Proteocephalidae), Parasites of Fishes in Europe 1998. Praha, Czech Republic. Academia. 1998, pp 1-118.

10. Wicht B, Yanagida T, Scholz T, Ito A, Jiménez JA, Brabec J. Multiplex PCR 16 for differential identification of broad tapeworms (Cestoda: Diphyllobothrium) infecting humans. J Clin Microbiol 2010; 48: 3111-3116

11. Kumar S, Stecher G, Li M, Knyaz C, Tamura K. MEGA X: molecular evolutionary genetics analysis across computing platforms. Mol Biol Evol 2018; 35: 1547-1549.

12. Kimura M. A simple method for estimating evolutionary rate of base substitutions through comparative studies of nucleotide sequences. J Mol Evol 1980; 16: 111-120.

13. Drummond AJ, Suchard MA, Xie D, Rambaut A. Bayesian phylogenetics with BEAUti and the BEAST 1.7. Mol Biol Evol 2012; 29: 19691973.

14. Flores JM, Vidaurre MT, Rivera ML, Rosales MC. Diphyllobotrium pacificum en niños del Perú. Diagnostico 2002; 41: 161-164 (in Spanish).

15. Pastor-Valle J, González LM, Martín-Clemente JP, Merino FJ, Gottstein B, Gárate T. Molecular diagnosis of diphyllobothriasis in Spain, most presumably acquired via imported fish, or sojourn abroad. New Microbes New Infect 2014; 2: 1-6.

16. Kuchta R, Esteban JG, Brabec J, Scholz T. Misidentification of Diphyllobothrium species related to global fish trade, Europe. Emerg Infect Dis 2014; 20: 1955-1957.

17. Londoñe-Bailón P, Céspedes-Chombo R, Pereyra KD. Evaluación de la presencia de Adenocephalus pacificus en pescados de mayor consumo en el Perú en el periodo 2016-2017. Rev InvVet Perú 2020; 31: e17552 (in Spanish).

18. Leštinová K, Soldánová M, Scholz T, Kuchta R. Eggs as a suitable tool for species diagnosis of causative agents of human diphyllobothriosis (Cestoda). PLoS Negl Trop Dis 2016; 10: e0004721. 